\title{
HOTELIER: A PASSION OR A PROFESSION?
}

\author{
Agung Gita Subakti \\ Hotel Management, Faculty of Economic and Communication, BINUS University \\ Jln. K. H. Syahdan No. 9, Palmerah, Jakarta Barat 11480 \\ agsubakti@binus.edu
}

\begin{abstract}
The history of hotels is intimately connected to that of civilizations. Or rather, it is a part of that history. Through years and time, many people are making their mark in the hotel industry by gaining the title as a Hotelier. Not just nationwide but they placed their footsteps throughout the world and became leading people in the Hospitality industry. The aim of this paper is to overview some of the people who had achieve the reputation as an Hotelier: globally recognized, set up their set of high quality standard, developing international brand and be able to sustain and succeed worldwide.
\end{abstract}

Keywords: hotelier, hotel

\begin{abstract}
ABSTRAK
Sejarah hotel berhubungan erat dengan peradaban daerah tersebut. Atau lebih tepatnya, hotel merupakan bagian dari sejarah. Bertahun-tahun,banyak orang meninggalkan jejak mereka di industri perhotelan dengan memperoleh gelar sebagai Hotelier. Tidak hanya dalam skala nasional, mereka menjejakkan diri di seluruh dunia dan menjadi orang terkemuka di industri perhotelan. Penelitian ini bertujuan untuk menggambarkan secara umum beberapa orang yang telah mendapat reputasi sebagai seorang Hotelier: diakui secara global, mengatur perangkat standar kualitas tinggi mereka, mengembangkan merek internasional, dan mampu mempertahankan serta berhasil di seluruh dunia.
\end{abstract}

Kata kunci: hotelier, hotel 


\section{INTRODUCTION}

The history of hotels is intimately connected to that of civilizations. Or rather, it is a part of that history. Facilities offering guests hospitality have been in evidence since early biblical times. The Greeks developed thermal baths in villages designed for rest and recuperation. Later, the Romans built mansions to provide accommodation for travelers on government business. The Romans were the first to develop thermal baths in England, Switzerland and the Middle East. Later still, caravanserais appeared, providing a resting place for caravans along Middle Eastern routes. In the Middle Ages, monasteries and abbeys were the first establishments to offer refuge to travelers on a regular basis. Religious orders built inns, hospices and hospitals to cater for those on the move.

Donald Albrecht wrote: Hotels are building that have been reinvented and re imagined for two hundred years- now more so than ever. Since the nineteenth century, hotels, whether in cities or remote oases, have evolved from simple places to sleep while on the road into elaborate destinations that combined private guestrooms, with restaurants, lounges, gyms, spas, meeting facilities and ballrooms. Architecture has become experience (Turkel, 2009).

The history of hotels is intimately connected to that of civilizations. Or rather, it is a part of that history. Facilities offering guests hospitality have been in evidence since early biblical times. The Greeks developed thermal baths in villages designed for rest and recuperation. Later, the Romans built mansions to provide accommodation for travelers on government business. The Romans were the first to develop thermal baths in England, Switzerland and the Middle East.

Later still, caravanserais appeared, providing a resting place for caravans along Middle Eastern routes. In the Middle Ages, monasteries and abbeys were the first establishments to offer refuge to travelers on a regular basis. Religious orders built inns, hospices and hospitals to cater for those on the move. Inns multiplied, but they did not yet offer meals. Staging posts were established for governmental transports and as rest stops. They provided shelter and allowed horses to be changed more easily. Numerous refuges then sprang up for pilgrims and crusaders on their way to the Holy Land.

Travelling then became progressively more hazardous. At the same time, inns gradually appeared in most of Europe. Some of them have remained famous, for example, l' Auberge des Trois Rois in Basle, which dates from the Middle Ages. Around 1200, staging posts for travelers and stations for couriers were set up in China and Mongolia. In Europe, or more precisely in Belgium, l' Auberge Cour Saint Georges opened in Gant, while the Angel Inn was built at Grantham in Lincolnshire, England.

\section{The Start of the Hotel Industry}

In France, at the beginning of the fifteenth century, the law required that hotels keep a register. English law also introduced rules for inns at that time. At the same time, around 1500 thermal spas were developed at Carlsbad and Marienbad. During this epoch, more than 600 inns were registered in England. Their architecture often consisted of a paved interior court with access through an arched porch. The bedrooms were situated on the two sides of the courtyard, the kitchen and the public rooms at the front, and the stables and storehouses at the back. The first guide books for travelers were published in France during this period.

An embryonic hotel industry began to develop in Europe. Distinctive signs were hung outside establishments renowned for their refined cuisine. At the end of the 1600s, the first stage coaches following a regular timetable started operating in England. Half a century later, clubs similar to English gentlemen's clubs and Masonic lodges began to appear in America. 
In Paris in the time of Louis XIV, the Place Vendôme offered the first example of a multipleuse architectural complex, where the classical façades accommodated boutiques, offices, apartments and also hotels. In New York first of all, and then in Copenhagen, hotels were established in city centres. At the beginning of the 1800s, the Royal Hotel was built in London. Holiday resorts began to flourish along the French and Italian rivieras.

In Japan, Ryokan guest houses sprang up. In India, the government-run Dak bungalows provided reliable accommodation for travelers. The Tremont House in Boston was the first deluxe hotel in a city centre. It offered inside toilets, locks on the doors and an "à la carte" menu.

In 1822, in Venice, a certain Giuseppe Dal Niel transformed an old palace into a hotel and gave it his name, "Le Danieli". As trains began to replace horse-drawn transport, highway inns for stage coaches started to decline. During this period, the Shepherds Hotel in Cairo was founded, the result of a complete transformation of an ancient city-centre harem.

L'Hôtel des Bergues was built in the spring of 1834 on the shore of the Lake of Geneva. One of its founders, Guillaume Henri Dufour, became a famous Swiss general. In 1840, l'Hôtel des Trois Couronnes was established in Vevey in Switzerland and the Baur au Lac in Zurich, fully refurbished since 1995.

The "Bayerischer Hof" was built in Munich in 1841, followed in 1852 by the "Vier Jahreszeiten". These two famous establishments were completely renovated after the Second World War. The third boom in the hotel industry began in 1980, marked by more inventive marketing and the development of hotels increasingly adapted to a particular type of clientele.

This trend prompted the construction of hotels near airports, hotels for conferences, health hotels, ski holiday hotels, holiday villages and marina hotels. The first Property Management Systems (Fidelio, Hogatex, etc.) appear in the hospitality market.

In Istanbul in 1984, work began on the renovation and transformation into a hotel of the prestigious sultans' residence, the Ciragan Palace in Istanbul. The resulting hotel is no less prestigious than the Ciragan Palace was. Managed by the Kempinski chain, it opened its 322 rooms to guests in 1991.

The first administrative hotel management systems, offering hotels greater independence from human resources, then appeared on the market. The hotel industry was becoming more and more competitive. Business travelers and retired people became important target customers.

In the eighties, too, the Far East began to prepare itself to welcome both business people and the tourists who were beginning to discover the countries of the rising sun, such as China, South Korea, Thailand and Japan. The international chains (American for the most part) prepared expansion plans for Europe, the Middle and Far East which were mainly aimed at congress participants and business people. The early nineties were characterized by a recession in the hotel business, without doubt caused by reductions in multinationals' travel budgets and the growing crisis in the Gulf.

The Gulf War helped to create great insecurity for both individuals and business. 1991 is considered to be the black year of the hotel trade. It forced hoteliers to become more creative in finding ways of attracting guests (special programmes, offers for "frequent travelers", high performance reservation systems) and thus emerge from the crisis with the minimum damage.

For the first time, the environment and energy conservation played an important role in the marketing activities of numerous chains (thanks in part to the green movement) and even helped to win the loyalty of numerous clients while safeguarding assets at the same time. 
Reservation systems became more efficient and offered the hotelier a new dimension in the creation of customer loyalty, the database. The records of each guest's individual history have helped create individualized marketing programmes and have enabled hotels to satisfy a guest's personal needs from the moment of his arrival.

Hotel Adlon Berlin is a legend reborn. From its opening in 1907, until it was destroyed in 1945, it was a symbol of Berlin, a lavish host for royalty, heads of government, stage and screen stars, and the greats of literature and science. Now, it has been rebuilt (1997) on its original site, the corner of Unter den Linden and Pariser Platz, facing the Brandenburg Gate. Outside, it is a virtual replica of the original; inside it is testimony to what smart hotel operators (in this case the Kempinski group) can accomplish with an investment of \$260 million. The hotel's 337 rooms and suites are the ultimate in luxury. Interiors, designed by England's Ezra Attia and Sweden's Lars Malmquist, dazzle with marble, sandstone, stained glass, gold leaf, stuccowork, cherry wood panelling, and damask draperies. This hotel is today equipped with the most advanced technology with regards to the Room Management System communicating with the Property Management System.

Since 1992, the most important international chains have been vying with each other in ever greater imaginative feats related to the vital process of renovating their establishments worldwide. Technology has started to take its rightful place in hotel administration (simplification of check-in and check-out procedures, global reservation systems, marketing management etc.). In 1995, the first Hotel Room Management System is launched at the European level. It is linked to the most popular Property Management Systems to make the front desk more efficient and near to the guests.

Hotel chains have been searching for alliances and some of them. For example: Holyday Inn, Intercontinental, and Crown Plaza have merged to form Six continents hotels Chain; Marriot absorbed Renaissance and Ramada International; Sol Melia opened a new line of Boutique hotels, Accor signed several joint ventures in the East and the Far East, etc.) Forte acquired Méridien to reinforce its global position. Starwoods (Sheraton) absorbed the Italian Ciga chain and Westin. The main expansion zones for the hotel industry in 1994 remained Asia (particularly China and India), the Middle East (above all, the United Arab Emirates and Egypt) and Latin America.

In Europe, hotel enterprises in the eastern countries (Russia, Croatia, Slovakia, etc.) decided to renovate dilapidated palaces built at the turn of the century. All the European capitals started to invest in preparations for the major event of this fin de siècle period, that is, the celebration of our entry into the third millennium.

The 3 star hotel Millennium enjoying top level of On-line Room Management System is situated at the best site in Opatija at the Mediterranean coast. Opatija in Croatia corresponds, in terms of reputation, to the level of St. Moritz in Switzerland.

Major hotel chains are drawing up development plans in almost all parts of Europe. These plans primarily involve the renovation of numerous prestigious hotels in both western and eastern European countries. Gradually, the great capitals of Europe have been endowed with hotels boasting three, four and five stars, offering quality services, innovative architecture, style, charm, and interior design (city Boutique hotels). Specialized hotels offer wellness programs including health and beauty centers, personalized services and treatments, anti-stress, revitalizing, regenerating programs, etc.

In 1995 construction began in Dubai of one of the most ambitious and prestigious tourist complexes in the region, the Jumeirah Beach Hotels (Jumeirah Beach hotel, Burj Al Arab, etc.). These comprise several establishments capable of satisfying the needs of average tourists, business people and those who can afford real luxury. The talk now is of six- and seven-star hotels, a surprising designation which is nevertheless perfectly justified by the luxury of the bedrooms and the facilities they offer, the impeccable service, the high degree of modern technology, as well as the beauty of the surroundings and the high-quality environment (Bonvin, 2004). 


\section{The Occupation of Hotelier}

Hoteliers have often been described as kings in their castles, (Keith, 2004) dispensing summary justice to their subjects, but the industry has gone through a major transition over the past 20 years. At the start of the 1980s, most hotels were run by professionals who had spent their formative years in a craft apprenticeship, either in the kitchens, restaurant service or front-desk.

They had worked their way up through a series of jobs of increasing responsibility. Long hours and extreme dedication were the hallmarks of their success, and they expected no less from their subordinates. Through their excellent apprenticeship systems, Switzerland, Germany, France and Austria produced a surplus of ambitious hoteliers who soon left their native lands to gain experience internationally. Their hands-on, detail-orientated, operational style became the role model for today's successful hoteliers.

A hotelier is a person who oversees or manages a hotel. He or she may be the owner of the establishment, the chairperson of the board that operates the hotel, the chief executive of a hotel location or chain, or the general manager of the hotel. Depending on how the term is applied, the responsibilities of a hotelier will vary. One who owns a hotel will be responsible for taking care of all matters common to the ownership of real estate, as well as carrying ultimate liability for any and all taxes and proper compliance with building codes and local laws regarding the operation of the hotel. The chief executive that carries the title of hotelier will oversee much of the promotional and general business aspects of the operation, as well as be accountable to the owner or owners for the profitability of the facility. The hotelier who is also chairperson of the board will provide a line of communication to investors and owners on the current status of the hotel, while the hotel manager will provide supervision of a wide variety of functions that impact the day to day operation of the hotel.

Many people started their career in Hospitality industry by choosing Hotel as their first step to success, each and every person had their own individual experience due to the dynamically hotel is. There are people who only took less than five years to stand in the Managerial levels, while others are struggling to survive in lower lever. Again, it depends on how every individual who choose Hotel as their path of career to develop their skills and knowledge. Some are lucky enough to have a conducive environment where training and development are being given intensively while somewhere those things are remain unimportant.

\section{RESULTS AND DISCUSSION}

\section{Top Ten Legendary Hoteliers}

However, there are some people who stood differently, these are the people who were born with passion to serve others, and these people are the inventor of service excellence, rules and regulation, standard operation procedures, and brand that recognize throughout the world. These are the legendary hoteliers.

\section{Cesar Ritz}

If there was ever a name that was synonymous with the very best of hotels it's Ritz. And the man responsible for this was hotelier Cesar Ritz. Born in Niederwald, Switzerland, to a farming family, he began his career at Le Splendide, a hotel in Paris and was maître d'hôtel at Chez Voisin. In 1878, he became the manager of the Grand Hôtel National in Lucerne and held the same position, in parallel, at the Grand Hôtel in Monaco until 1888. Ritz's strength was his ability to understand the needs and desires of wealthy customers and this led to him pioneering the foundations of what we would come to know as luxury hospitality. 
In 1888, he opened a restaurant with Auguste Escoffier (thought of by many as the father of modern French cooking) in Baden-Baden, and the two were then invited to London by Richard D'Oyly Carte to become the first manager and chef of the Savoy Hotel.

Ritz is quoted as saying that he put together "a little army of hotel men for the conquest of London". Under Ritz, The Savoy went from strength to strength and royalty, extremely rich clientele and the powerful could be seen frequenting the hotel and its supper rooms.

In 1898, he opened the celebrated Hôtel Ritz in the Place Vendôme, Paris, France. He went on to open The Ritz Hotel in London, United Kingdom in 1906, which became one of the most popular meeting places for the rich and famous. The partnership lasted until Ritz had to retire in 1907 due to deteriorating health. Ritz died in Küssnacht, near Lucerne, Switzerland at the age of 68. Many of the touches that Ritz introduced to his hotels are still standard practice in today's modern luxury hotels. That is why he has secured his place in the Top 10 Legendary Hoteliers (The Ritz Carlton, 2012).

\section{Conrad Hilton}

Who hasn't heard of Hilton? That's right, nobody. And while some of today's generation may first think of his blonde granddaughter, hoteliers conjure up the legend that was Conrad Hilton. Hilton developed his entrepreneurial flair while working as a young boy in his father's general store in New Mexico. He purchased his very first hotel in 1919, a 40-room property called Mobley Hotel in Texas.

The purchase of the property was a matter of chance, as originally Hilton planned to invest his money in a bank, but the plan fell through. Luckily it paid off, as the hotel business boomed and he expanded his portfolio across the state. His first high rise hotel was the Dallas Hilton which he opened in 1925 before expanding into New Mexico. However, trouble loomed and when the Great Depression hit, Hilton was forced to sell some of his hotels to avoid bankruptcy.

Despite this he was retained as manager of the hotels and bought them back when the economic climate improved. In 1946 he formed Hilton Hotels Corporation followed by Hilton International Company in 1948. Fuelling American's desire for travel and business on a global scale, Hilton became the first international hotel chain, a truly remarkable feat. He passed away in January 1979 but his legacy is still thriving as the multitude of international lodging companies vie for opportunities in every corner of the world (Hilton, 2012).

\section{Bill Marriott Jr.}

However, despite J. Willard being the founder of Marriott and the hotel group's mentor, it was his son 'Bill' who took the company and turned it into the hospitality giant it is today. His leadership spans more than 50 years and he has taken Marriott from a family restaurant business to a global lodging company with more than 3,100 properties in 67 countries and territories.

Known throughout the industry for his tireless work ethic and his attention to detail, it was his decision to follow a franchise model that allowed the company to compete on the global stage. His business innovations and ability to oversee a company that is consistently honored as being a top company to work for firmly establishes his position on the list. (Marriott, 2012)

\section{Kemmons Wilson}

Hotel, motel, Holiday Inn. The man responsible for creating the hotel chain famously mentioned in Rapper's Delight by the Sugarhill Gang was a man by the name of Kemmons Wilson. Following a thoroughly disappointing holiday to Washington DC in terms of the standard of roadside accommodation, Wilson decided to do something about it. 
He opened his first hotel in Memphis in 1952. The story goes that Kemmons' architect, Eddie Bluestein, joked that he should name it after a reference to a Bing Cosby Movie of the same name. But the idea stuck and other properties were quickly adopting the Holiday Inn name.

In 1957, Wilson franchised the chain as Holiday Inn of America and it grew dramatically, following Wilson's brief that the properties should be standardized, clean, predictable, family-friendly and readily accessible to road travelers. By 1958, there were 50 locations across the country and 100 by 1959.

In 1960 the chain went international. There were 500 hotels by 1964, and the 1000th Holiday Inn opened in San Antonio, Texas, in 1968. By this time the chain was dominating the market, making use of its innovative Holidex reservation system.

In June 1972, Wilson was featured on the cover of Time magazine. Clever innovations such as indoor pools had turned the image of the often run down motel into one of a roadside resort, all to do with Kemmons' desire for quality accommodation while on the go. A true pioneer in the world of modern hospitality and therefore deserves his place in the Top 10 Legendary Hoteliers (The History of Holiday Inn Hotels, 2012).

\section{Barry Sternlicht}

As the founder of Starwood Hotels and Resorts, Barry Sternlicht is a real estate developer with an eye for a property and the ability to realise a brand. Many of his creations have been copied, the sincerest form of flattery.

Born in New York City in 1960, Sternlicht got his MBA from Harvard Business School in 1986. His first job after Harvard was with Chicago-based JMB Realty, where he became a sensation, but was fired before the savings and loan crisis. He had a friend who handled money for the ultrawealthy Burden and Ziff families who offered to back him with \$20 million if he started his own investment firm. Others joined in, and in 1992, Sternlicht launched Starwood Capital Group.

His goal was to buy up multi-family apartment buildings that were being auctioned off in the government's bailout of the savings and loan crisis. In 1993, Sternlicht sold the portfolio to real estate magnate Sam Zell for more than 20 percent of Zell's Equity Residential Properties Trust. When Zell took the company public that year, Starwood saw a 100 percent return. Sternlicht later began to purchase hotel sites, focusing on combining his passions of architecture and real estate finance. Starwood Capital also bought its first hotels, kicking off the series of moves that would realign the hospitality industry. The first was the acquisition of Westin Hotels \& Resorts Inc and one month later, Starwood Hotels completed the purchase of ITT Sheraton Corp. for \$14.6 billion.

The hotel business, meanwhile, had proven to be tailor-made for Sternlicht's wide-ranging interests in capital markets, operations, marketing and design. Having shaken up the hotel industry's dynamics through mergers, he contributed a number of other influential innovations. In 1999 he started the popular Starwood Preferred Guest program, credited with being the first "no blackout" program in the industry. In the same year he went on to develop the luxury ST Regis brand following the purchase of the century-old St. Regis Hotel in Midtown Manhattan. (Starwood Hotels \& Resorts, 2012)

\section{Paul Dubrule/Gerard Pellisson}

The influence of men such as Kemmons Wilson crossed the pond in the late 1960s when two Frenchman, who had been working in America, formed the SIEH (Société d'investissement et d'exploitation hôteliers) hotel group. Paul Dubrule and Gérard Pélisson had witnessed firsthand the success of the hotel business along major highways and suburban areas and they were determined to bring the concept to France. 
They opened their first American-syle Novotel hotel outside of Lille in northern France and in 1974 launched the Ibis brand with the opening of the Ibis Bordeaux. In 1975 the company took on the Courtepaille and Mercure brands, followed by the Sofitel brand in 1980 .

Two years later, in 1982, the SIEH bought out Jacques Borel International, the then worldleading brand offering restaurant vouchers. In 1983, the Group, which had restaurant tickets and hotels, changed its name to the Accor Group in 1984, Dubrule and Pélisson were elected "Managers of the Year" by France's Le Nouvel Économiste magazine.

Both men have gone on to represent the hospitality and travel industry in many ways, but it was their determination to bring Europe in line with modern American lodging and the subsequent international brands they developed that secure their place in the list. (Accor, 2012)

\section{Jay Pritzker}

When looking at the Pritzkers, the family who founded Hyatt, it is hard to pick out an individual who isn't worth a mention. Having dominated the Forbes' rich list since its inception, the business success stories of the Pritzkers are numerous. And while the day-to-day running of the hotel company was originally Donald Pritzker's role, we are recognising Jay Pritzker for his simple, but brilliant realisation. In 1957, Jay Pritzker, a trained lawyer and accountant, had been buying small companies, something he had done since he was 29.

He was sat in Fat Eddie's coffee shop at Los Angeles International Airport and realised it was very busy. Added to this was the fact the hotel it was located in, Hyatt Von Dehn (named after its owner) had no vacancies, writing his offer of US \$2.2 million on a napkin.

Pritzker knew, not unlike Kemmons Wilson wanting quality roadside lodging, that business executives like himself would want to stay at a quality hotel near a large airport. With his brother Donald the pair set about building hotels near airports in Los Angeles, San Francisco and Seattle, then around the country and internationally.

In 1967, Pritzker bought a half-finished hotel in Atlanta and turned it into the Hyatt Regency. The first of the giant atrium hotels, the Hyatt Regency Atlanta struck doubters as a white elephant. There were people who even said rainstorms would form inside the lobby due to its size. Pritzker died in 1999, but his legacy continues across the globe. (Hyatt, 2012)

\section{PRS Biki Oberoi}

When the eyes of many hoteliers were firmly fixed on the West, Prithvi Raj Singh Oberoi, better known as Biki Oberoi, was looking East. P.R.S. Oberoi, chairman and CEO, EIH Limited, the flagship company of The Oberoi Group, and chairman of Oberoi Hotels Private Limited, is the son of late Rai Bahadur M.S. Oberoi, the founder of The Oberoi Group.

Under his guidance, this legendary hotelier has pioneereed the development of the new Oberoi hotels and resorts. But it didn't always seem that he would make a name for himself. He admitted he did little work until he was 40 as his father had told him to go out and see the world. He admitted in an interview that the first hotel he ran was Maidens, but he "didn't do it very seriously". "There was a general manager there, so I used to meet him two hours in afternoon and party in the evening," he added.

But that all changed when he opened Raj Villas, a concept that boasted sprawling gardens with luxury tents and villas. An international audience took notice and it was one of the best hotels in the world, placing India's flag in the luxury hotel map. More hotels have followed and it is not unusual to see several Oberoi hotels gracing top hotels in the world lists. 
He has won numerous international awards and titles for his tireless efforts in hospitality and in January 2008, was awarded the Padma Vibhushan, India's second highest civilian honour, in recognition of his exceptional service to the country. In the same year he was conferred the Lifetime Achievement Award at the Ernst \& Young Entrepreneur of the Year Awards for redefining design standards in luxury hotels (Oberoi Hotels, 2012).

\section{Ian Schrager}

Not many people can be attributed with starting a whole new genre of hotel lodging, but Ian Schrager is on our list for doing exactly that. Known outside of hotel circles for being one half of the duo behind the infamous Studio 54 nightclub in New York - the haunt of the famous and beautiful in the late $70 \mathrm{~s}$ - Schrager had to turn his attention to other revenue streams when he was convicted of income tax evasion on the club.

As he was unable to obtain a liquor license he bought the Executive Hotel. Reopening it as the Morgans Hotel, in 1984, the property became a success and allowed for the opening of the Century Paramont Hotel, as well as the acquisition and renovation of the Royalton in 1988.

Schrager's new company, the Morgans Hotel Group, went on to open the Delano Hotel, in Miami, and the Sanderson Hotel and the St. Martin's Lane Hotel, in London, the Clift, in San Francisco, and the Mondrian Hotel, in Los Angeles. By 1998, Schrager was the largest private hotelier in New York and was known across the globe for his 'boutique-style' of hotel.

Sometimes known as 'design hotels' or 'lifestyle hotels', typically boutique hotels were furnished in a themed, stylish and/or aspirational manner. They usually are considerably smaller than mainstream hotels, often ranging from three to 50 guest rooms.

In 2005, Schrager left Morgans Hotel Group to create the Ian Schrager Company, and collaborated with artist and filmmaker Julian Schnabel on the Gramercy Park Hotel. He then formed a partnership with Marriott International, with the EDITION hotel brand, which launched its first hotel in Hawaii on October 15, 2010-The Waikiki EDITION. (Morgans Hotel, 2012)

\section{Future Hotelier?}

The last number were kept blank for the future hoteliers, who will be the next big thing? Do you believe Isadore Sharp should be lauded for the Four Seasons? Did Horst Shulze do enough at the helm of Ritz-Carlton to warrant a spot? Have we been amiss in missing out Las Vegas mega-resort pioneer Kirk Kerkorian? Or perhaps Hoteliers arising from middle east? or from other parts of the world? Let the trends answer the questions.

\section{CONCLUSION}

Hotel companies today are looking for strengths in leadership, and communication skills which mobilize the energy and resources of a management team. Hoteliers are now expected to be visionaries, who see the future clearly and can articulate this vision so that others are inspired to follow. See the relationships among various ideas and information. They articulate, follow a clear mission and are guided by broad goals, as well as more short-term objectives. They spend time anticipating the future, as well as dealing with the present. They surround themselves with experts and are able to analyze and interpret the information they receive so that they can make wise decisions for their organizations. Sensitivity to, and appreciation of, diversity in individuals is an area in which the hotel industry is particularly attuned. 
Certain hoteliers are described as "having presence", or "filling the space around them". This is a consequence of their confidence to perform the specific tasks relevant to their roles. They feel empowered and proud of their contributions, and tend do be independent and self-directed. They do not depend on constant recognition from others to feel good about their jobs. They believe they can handle their job requirements under a wide range of conditions, and tend to seek new and challenging tasks. They have realistic self-assessments. Creativity and innovation are becoming recognized as highly valued management characteristics and, with the increasing rate of change, managers who respond creatively to new challenges and opportunities will be in demand in the next decade. And that is future Hotelier, a profession with passion.

\section{BIBLIOGRAPHY}

Accor. (2012). Retrieved December 10, 2012, from Accor: http://www.accor.com/en/group/history.html

Bonvin, J. L. (2004, December 15). Hotels | A Brief History - By Jacques Levy-Bonvin. Retrieved December 10, 2012, from Hospitality.net: http://www.hospitalitynet.org/news/4017990.html

Hilton. (2012). Retrieved December 10, 2012, from HIlton: www.hiltonworldwide.com/about/history

Hyatt. (2012). Retrieved December 10, 2012, from Hyatt: http://www.hyatt.com/hyatt/about/ourcompany/company-history.jsp

Keith, M. (2004, august). Defining a Hotelier; The Hotel Professional Has Gone Through a Major Transition Over the Past 20 Years. Retrieved December 10, 2012, from Hotel Online: http://www.hotel-online.com/News/PR2004_4th/Oct04_CanadaAugust.html

Marriott. (2012). Retrieved December 10, 2012, from Marriott: http://www.marriott.com/culture-andvalues/marriott-family-history.mi

Morgans Hotel. (2012). Retrieved December 10, 2012, from Morgans Hotel: www.morganshotelgroup.com

Oberoi Hotels. (2012). Retrieved December 10, 2012, from Oberoi Hotels: http://www.oberoihotels.com/about_us/founder_chairman.asp

Starwood Hotels \& Resorts. (2012). Retrieved December 10, 2012, from Starwood Hotels \& Resorts: http://www.starwoodhotels.com/luxury/about/detail.html?section=about\&parentCategory=abo ut\&category=history_heritage

The History of Holiday Inn Hotels. (2012). Retrieved December 10, 2012, from USA Today: http://traveltips.usatoday.com/history-holiday-inn-hotels-61884.html

The Ritz Carlton. (2012). Retrieved December 10, 2012, from The Ritz Carlton: http://corporate.ritzcarlton.com/en/About/OurHistory.htm

Turkel, S. (2009). Great American Hoteliers: Pioneers of the Hotel Industry. Bloomington: Author House. 